\title{
First report of Pythium aphanidermatum causing leaf spot on Digitalis purpurea in Italy
}

\author{
Angelo Garibaldi ${ }^{1} \cdot$ Giulia Tabone $^{1} \cdot$ Incoronata Luongo ${ }^{2} \cdot$ Maria Lodovica Gullino $^{1}$
}

Received: 12 August 2021 / Accepted: 15 October 2021 / Published online: 29 October 2021

(c) Società Italiana di Patologia Vegetale (S.I.Pa.V.) 2021

Keywords Oomycetes · Ornamentals · Gardens

In June 2021, punctiform leaf spots were observed on the old basal leaves of 4 to 5-month-old plants of Digitalis purpurea (Scrophulariaceae family) cultivated in mix borders in a private garden near Biella (Northern Italy, Piedmont). These alterations subsequently appeared on the young leaves and, by expanding along the petiole, caused the death of the affected leaves and, in some case, of the entire plants. Samples were collected from 5 of the 50 plants grown in the garden and white colonies were consistently isolated. A representative colony grown on PCA for 15 days showed aseptate hyphae of 2.9 to 9.2 (average 5.4) $\mu \mathrm{m}$ wide $(n=50)$. Sporangia were lobate and branched, while oogonia were globose, smooth and measured 20.8 to 36.9 (average 25.6) $\mu \mathrm{m}$ in diameter $(n=50)$. Antheridia were barrel-shaped, intercalary and diclinous. Oospores were globose and measured 16.4 to 24.4 (average 20.6) $\mu \mathrm{m}$ in diameter $(n=20)$. These morphological characteristics are consistent with the genus Pythium sp. (Watanabe 2002). The sequences of the gene COI (Robideau et al. 2011) (GenBank Accession No. MZ717162) were analyzed with BLASTn showing 99.82\% similarity with the ex-type CBS11880 of Pythium aphanidermatum (HQ708485). Two pathogenicity tests were performed on 2-month-old plants of D. purpurea. An aqueous suspension of oospores and mycelium obtained from a representative isolate coded 21-74-5 (Agroinnova collection, Torino) was distributed, at a concentration of $1 \times 10^{5} \mathrm{CFU}$ $(5 \mathrm{ml} / \mathrm{plant})$, on the leaves of three healthy plants. Three plants sprayed with deionized water were considered as controls. Plants were covered with a plastic transparent bag and kept in a greenhouse at $22-26{ }^{\circ} \mathrm{C}$ and $\mathrm{RH} 85 \%$. Three days later, punctiform leaf spots appeared on the basal leaves of the inoculated plants and a microorganism with the characteristics previously described was consistently isolated. Affected plants died ten days after the inoculation, while control plants remained healthy. According with the USDA updated list (Farr and Rossman 2021), this is the first report of $P$. aphanidermatum on D. purpurea in Italy as well as elsewhere.

\section{References}

Farr DF, Rossman AY (2021) Fungal Databases, U.S. National Fungus Collections, ARS, USDA. Retrieved August 6, 2021, from https:// nt.ars-grin.gov/fungaldatabases/

Robideau GP, De Cock AW, Coffey MD, Voglmayr H, Brouwer H, Bala K, André Lévesque C (2011) DNA barcoding of oomycetes with cytochrome c oxidase subunit I and internal transcribed spacer. Mol Ecol Resour 11:1002-1011

Watanabe T (2002) Pictorial atlas of soil and seed fungi. Morphologies of cultured fungi and key to species. CRC press, Florida, $485 \mathrm{pp}$

Publisher's Note Springer Nature remains neutral with regard to jurisdictional claims in published maps and institutional affiliations.

Giulia Tabone

giulia.tabone@unito.it

1 Centre of Competence for the Innovation in the Agro-Environmental Sector (AGROINNOVA), University of Torino, Largo Paolo Braccini 2, 10095 Grugliasco, Torino, Italy

2 University of Torino, Largo Paolo Braccini 2, 10095 Grugliasco, Torino, Italy 